https://doi.org/10.5817/OS2019-3-10

\title{
Středoevropanství Milana Kundery
}

JANIEC-NYITRAI, A., NYITRAI, Z.: Vrhat dvojitý stín. Středoevropanství jako osud $v$ románech Milana Kundery. Esztergom: Nadace svatého Vojtěcha pro výzkum střední a východní Evropy, 2017, 248 s., ISBN 978-963-89709-2-3.

Publikace autorské dvojice A.Janiec-Nyitrai a Z.Nyitraiho Vrhat dvojitý stín. Středoevropanství jako osud v románech Milana Kundery je výsledkem dlouholetého zájmu zahraničních (polských a madarských) slavistů jednak o fenomén střední Evropy, jednak o dílo Milana Kundery. Komplementární prostupování obou tematických linií představuje $\mathrm{v}$ chápání autorské dvojice interpretační klíč $\mathrm{k}$ románové poetice tohoto světoznámého prozaika, dnes už jen prozaika „českého původu“, který je znám jako perfekcionista a který u svých posledních textů, v podstatě od románu Pomalost ( $L a$ lenteur) v roce 1995, nesvolil k českému př̀kladu. Důvody spočívají zřejmě nejen v radikální autokritičnosti, ale i v mediálním ataku některých českých publicistů, kritiků a historiků připomínajících s jistou stereotypností autorovy rané dobově poznamenané texty z 50 . let minulého století a také jeho studentskou „občanskou aktivitu“, jež údajně vedla $\mathrm{k}$ jeho vědomému udavačství. ${ }^{1}$ Bez ohledu na pravdivost těchto názorů Kunderovo dílo bude vždy provokovat a své vnímatele umělecky a politicky rozdělovat. Autoři této monografie však „ideologizujíci“ rozměr ignorují a výhradně zkoumají, jak se kategorie stř̌edoevropanství promítá do textových struktur pětice Kunderových románů z přelomu 70. a 8o. let minulého století (od Žertu v roce 1967, do Nesnesitelné lehkosti bytí v roce 1984), zároveň analyzují recepční dosah možná dnes nejznámějšího, nejen esejistického Kunderova textu Únos Západu čili tragédie střední Evropy (1984), který v emigrantském prostředí několik let před pádem železné opony znovu vyvolal diskusi o středoevropské identitě na pozadí nejrozmanitějších intelektuálních diskursů.

Autoři v pěti přehledně koncipovaných kapitolách s úvodem a závěrem postupují od teoretického uchopení středoevropanství jako jisté tragické, eventuálně nostalgické existenciální zkušenosti přes obrysové načrtnutí vývojových kontextů spisovatele až ke zhodnocení relevantních publicistických a románových textů. Nejrozsáhlejší pátá kapitola, která v podstatě zabírá polovinu monografie Středoevropanství jako univerzální osud. Rozpětí mezi protipóly přináší detailní a minuciózně realizované průniky do složité motivické sítě sémiotických bipolárních opozicí (kýč × skutečnost,

1 Např. DRDA, A.: Problém udavače aneb velké Komu je M. K. podobný? In: DRDA, A. - KROUPA, M. (eds): V komunismu jsme žít nechtěli. Další kapitoly z rozhlasového pořadu Příběhy 2o. století. Praha: Radioservis 2009, s. 63-65. 
pravda $\times$ lež, tvář × maska, velké × malé dějiny apod.), které jsou pro dané období Kunderova směřování charakteristické. Autoři jsou si vědomi mnohoznačnosti a myšlenkové nejednotnosti či protikladnosti, kterou spisovatelovy esejistické a prozaické texty podněcují. Skepsi, zda je vůbec ještě možné něco nového napsat o Kunderově tvorbě, překonávají právě prohloubenou perspektivou středoevropanství, což jim - jak správně zdůrazňují - umožňuje nalézt kompromis mezi jazykově-etnickým a obecně univerzálním pohledem na vnitřně ambivalentní Kunderovo dílo, které lze hodnotit protikladnými metodami z nejrůznějších perspektiv a s rozmanitými dosaženými výsledky. V poslední době v soudobé české literární kritice a publicistice (J. Češka, T. Kubíček ad.) posílil názor, že proniknout $\mathrm{k}$ „tajemstvi“ spisovatelovy literární tvorby je možné pouze radikální dekonstrukcí stávajícího bádání a naopak „nasazením“ čistě naratologických technik, teorie fikčních světů apod. Stejně tak by šlo realizovat zdánlivě neotřelé „kunderovské čtení“ postkoloniální optikou či pečlivým luštěním textových manuskriptologických stop, pokud bychom např. měli k dispozici rukopisné varianty. Př́stup autorské dvojice je v tomto ohledu tradičnější a konzervativnější v dobrém slova smyslu; podle mého názoru se bliží pojetí K. Chvatíka a zahraničních bohemistů a slavistů (E. Le Grand, H. Janaszek-Ivaničkova, L. Hanko ad.), kteří píší o Kunderově filozofickém vyrovnávání s existenciální zkušeností Stř̌edoevropana, jenž se prostřednictvím románových struktur rozhodl meditovat o paradoxech dějin, do nichž jsou vrženy jeho příběhy. Lze tu souhlasit s Evou Le Grand v tom, že Kundera oživil středoevropskou filozofickou myšlenkovou tradici s jejím pluralistickým (antinomickým) pohledem na člověka a svět.

Zároveň nejde o biografii či klasický monografický portrét vycházející z interpretace pěti románových textů, ale o poučené hledání vazeb mezi „středoevropskosti“ a existencí románu nejen jako specificky strukturovaného žánru, ale i jako svébytné životní hodnoty vyjadřující zkušenost člověka za železnou oponou. Autoři se proto vracejí ke staronové identifikaci tvůrčích principů jako např. paradoxní smysl hry, ironie, náhody dějin apod. a hledají genetické souvislosti mezi teoretickými či esejistickými názory a románovými modely. Na pravou míru uvádějí také fenomén racionálního konstruování románové fikce, kde emocionalita je pouze doprovodnou součástí tvořivého úsilí o přesné, v podstatě fenomenologické vidění reality. Zde bych jen doplnil, že i přes emigraci se Kundera nikdy nevymanil z kontextu české prózy 6o. let inspirované vlnou tzv. intelektualizace jako jisté reakce na schematičnost budovatelské poetiky. Myslím, že je tu dobře postižen i tvořivý, jakýsi „stavebni“ paradox mezi „matematičností" a „hudebností". V současnosti se totiž klasický kompoziční rozbor považuje za cosi zastaralého a samozřejmého, o čem netřeba psát. Ačkoli Kundera v raném Umění románu horuje za obnovu tzv. velké epiky v hegelovském pojetí (od této iluze se Kundera později ostř̌e distancoval), vždy jde $\mathrm{v}$ jeho textech, $\mathrm{v}$ jeho kompozičních strukturách o oscilaci mezi epikou a lyrikou, 
mezi přesnou a zdánlivě jen lehce načrtnutou fabulací, o spor mezi sémantikou filozofické reflexe a subjektivizovanými psychologickými postřehy. Při analýzách jsou tyto problémy velmi dobře vysvětleny; připomenutí analogií mezi stavbou děl literárních a hudebních je oprávněné. Sám Kundera ho nepopírá, protože, jak známo, měl díky svému otci, skladateli Ludvíku Kunderovi (ten byl jedním z posledních žáků Leoše Janáčka) solidní znalost o zákonech harmonie a kompoziční polyfonie. Tudíž lze někdy, s jistou mírou skepse - uvažovat nad tím, zda staví svá témata, jednotlivé linie, postavy jako intonační „hlasy“ podle principů přísně vázané kombinace hudebních forem. Na druhou stranu i kombinatorická pravidla podléhají jako projev „umění“ prvkům improvizace, spontaneity, lehkosti a chaosu. Z tohoto hlediska je typický pro Kunderu kontrapunkt a tonalita fugy s přesným vedením hlasů, s jejich kompozičním proplétáním a pak závěrečným spojením. $V$ řadě rozhovorů ještě v 6o. letech v českém kontextu Kundera román přirovnával bud’ k symfonii, anebo $\mathrm{k}$ fuze.

Autoři pozornost věnují rovněž světoznámému eseji, který diskusi o střední Evropě vrátil z politologického diskursu do roviny literárně-filozofické. Jestliže jako distinktivní rysy středoevropskosti zde Kundera uvádí skepsi, ironii, sebeironii, nedůvěru $\mathrm{k}$ „velké" historii, mají autoři pravdu v tom, že tyto rysy jsou u spisovatele explicitně zakódované do narativních technik, uměleckých postupů, tj. do složitého komplexu románové struktury. Jen malé připomenutí, že V. Havel tento text anticipoval nejen v roce 1969 svým Českým údělem, ale polemicky navázal na něj v stati Anatomie jedné $z d r z ̌ e n l i v o s t i$ (1985), kde střední Evropu chápe jako kulturní a především morálně-mentální fenomén. Je tu rovněž zklamání z ideologií, ale na rozdíl od Kundery i zidealizovaná demokratická vize tohoto prostoru jako prátelského společenství svobodných a nezávislých národů. Po roce 1989 Havel dokonce hovořil o šanci proměnit tento fenomén $\mathrm{z}$ duchovního a historického rozměru na fenomén politický (HAVEL, V.: Projevy. Leden-červen 1990. Praha 1990).

Autoři velmi dobře stylizují, text je srozumitelně napsán, přičemž soupis prostudované literatury ukazuje na solidní znalost dnes již nepřehlédnutelných položek domácího a zahraničního kunderovského bádání. Česky psaná monografie se zařazuje do žánrového kontextu hodnotných publikací mapujících rozmanité myšlenkové a umělecké kontexty Kunderovy románové poetiky. Zároveň potvrzuje dlouhodobý zájem zejména středoevropských literárních badatelů o Kunderovo složité a polytematické dílo, které dosáhlo nejen světového ohlasu, ale je i stále masově čteno domácími i zahraničními čtenáři. Nezbývá než doufat, že v další autorské spolupráci, např́iklad bohemisty a romanisty, se objeví analýza především posledních čtyř románů, již vzpomenuté Pomalosti, dále Totožnosti (L’identité, 1998), Nevědomosti (L'ignorance, 200o) a Slavnosti bezvýznamnosti (La fete de linsignifiance, 2013). 


\section{Literatura:}

DRDA, A.: Problém udavače aneb velké Komu je M. K. podobný? In: DRDA, A. - KROUPA, M. (eds): V komunismu jsme žít nechtěli. Další kapitoly z rozhlasového pořadu Příběhy 20. století. Praha: Radioservis 2009.

HAVEL, V.: Projevy. Leden-červen 1990. Praha 1990.

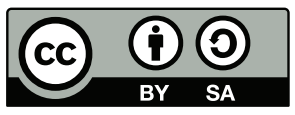

Toto dílo lze užít v souladu s licenčními podmínkami Creative Commons BY-SA 4.0 International (<https:// creativecommons.org/licenses/by-sa/4.0/legalcode>). Uvedené se nevztahuje na díla či prvky (např. obrazovou či fotografickou dokumentaci), které jsou v díle užity na základě smluvní licence nebo výjimky či omezení príslušných práv.

\section{Proměny kulturologických koncepcí ve středoevropském kontextu}

POSPÍŠIL, I., GUNIŠOVÁ, E. (eds): Střední Evropa včera a dnes: proměny koncepcí II: (jazyk - literatura - kultura - politika - filozofie). Brno: Středoevropské centrum slovanských studií, 2018. 393 stran. ISBN 978-80-88296-01-o.

Obsáhlá kolektivní monografie s názvem Střední Evropa včera a dnes: proměny koncepcí II: jazyk - literatura - kultura - politika - filozofie o rozsahu téměř čtyř set stran bezprostředně navazuje na svou první část a byla vydána péčí Středoevropského centra slovanských studií, z. s., v těsné spolupráci s Ústavem slavistiky FF MU, Českou asociací slavistů a Slavistickou společností Franka Wollmana.

Tato zajímavá publikace je pestrou analýzou různých náhledů na střední Evropu a zdařilým pokusem o vystižení toho, jaká role je dnes střední Evropě přisuzována $\mathrm{v}$ celoevropském myšlení. Jak v anglicky fundovaně psané předmluvě Hledání střední Evropy uvádí její autor Ivo Pospíšil (Česká republika), středoevropský prostor představuje složitý a spletitý kulturní komplex, region s pestrými a bohatými historickými a náboženskými událostmi, kolébkami revolucí a světovými válkami.

V reprezentativní knize jsou v abecedním pořádku představeny jednotlivé statě, které jsou vždy na začátku opatřené krátkou anotací a klíčovými slovy v původním jazyce článku (angličtina, čeština, polština, ruština, slovenština, ukrajinština) a abstraktem a klíčovými slovy v angličtině. 